\title{
Fever, Malaise and Arthralgia: Brucellosis or Salmonellosis in the Differential Diagnosis in an Endemic Area
}

\author{
Ateş, Halsizlik ve Artralji: Endemik Bir Bölgede Ayırıcı Tanıda \\ Bruselloz ve Salmonelloz
}

\author{
Başak Yıldız Atikan' (ID), Gülhadiye Avcu'(ID) \\ ${ }^{1}$ Clinic of Pediatric Infectious Diseases, Balikesir Ataturk City Hospital, Balikesir, Turkey
}

Cite this article as: Yıldız Atikan B, Avcu G. Fever, malaise and arthralgia: brucellosis or salmonellosis in the differential diagnosis in an endemic area. J Pediatr Inf 2020;14(3):e106-e110.

\section{Abstract}

Objective: Brucellosis and salmonellosis are both infectious, zoonotic and endemic diseases in Turkey. In this study, we aimed to report a group of pediatric patients admitted to the hospital with fever, malaise and arthralgia and diagnosed with either of the diseases.

Material and Methods: We retrospectively analysed hospital records for gender, age, consumption of raw milk products, laboratory results, organ involvement, treatment choices and course of the disease.

Results: Out of a total of 36 children, 30 were diagnosed with brucellosis and 6 with salmonellosis in two years. A total of 20 patients of 30 cases (66\%) diagnosed with brucellosis notified exposure to animals. Except two of these patients, they usually confirmed that they consumed raw milk or cheese made with unpasteurized milk. Only 2 cases of the residual 6 cases diagnosed with salmonellosis had contact with animals and consumed raw milk or meat products. Their sources of infections remain unclear. Fever, malaise and arthralgia were most frequent symptoms, and hepatosplenomegaly was the most common extraarticular manifestation in both conditions. All patients are in remission except two cases of brucellosis with disease relapse in follow up, and one case with hemophagocytosis and prolonged disease and the need for additional chemotherapy.

Conclusion: Despite effective eradication programmes for both diseases, they still remain important health problems and cause disease burden.

Keywords: Brucellosis, salmonellosis, childhood
Öz

Giriş: Bruselloz ve salmonelloz ülkemizde endemik olarak görülen enfeksiyöz ve zoonotik hastalıklardır. Bu çalışmada hastanemize ateş, halsizlik ve eklem ağrısı yakınması ile başvuran ve bu iki hastalık açısından tetkik edilerek biri ile tanı almış pediatrik olgular geriye dönük olarak incelenmesi amaçlanmıştır.

Gereç ve Yöntemler: Hastaların yaş, cinsiyet, çiğ süt ve süt ürünü tüketim öyküleri, klinik ve laboratuvar bulguları, organ tutuluşları, tedavi uygulamaları ve prognozları retrospektif olarak değerlendirilerek sunulmuştur.

Bulgular: İki yıllık süreçte toplam 36 olgunun 30'u bruselloz, 6'sı salmonelloz tanısı almıştır. Brusella tanısı alan 30 olgunun 20'si hayvan teması olduğunu ve 2 olgu dışında hepsi çiğ süt ve süt ürünü tüketimi olduğunu belirtmiştir. Salmonelloz tanısı alan 6 olgunun ise 2'sinin ailesi ise hayvancılıkla uğraşmakta olup, diğer olgularda enfeksiyon kaynağına dair bir gösterge bulunamamıştır. Ateş, halsizlik ve artralji en sık görülen semptomlar olup her iki hastalıkta hepatosplenomegali en sık görülen ekstraartiküler bulgudur. Bruselloz tanılı 17 olgudan 3'ünde relaps görülmüştür. İzlemde hemofagositoz gelişen ve kemoterapi ihtiyacı doğan bir olgu dışında tüm olgularda remisyon sağlanmıştır.

Sonuç: Her iki hastalığa yönelik eradikasyon programlarının uygulanması ve kontrol çabalarına rağmen özellikle bruselloz, endemisite göstermesi açısından ülkemizde hâlâ önemli bir sağlık sorunu olarak karşımıza çıkmaktadır.

Anahtar Kelimeler: Bruselloz, salmonelloz, çocukluk çağı

\author{
Correspondence Address/Yazışma Adresi \\ Başak Yıldız Atikan \\ Balıkesir Atatürk Şehir Hastanesi, \\ Çocuk Enfeksiyon Hastalıkları Kliniği, \\ Balıkesir-Türkiye \\ E-mail: basakyildiz@gmail.com
}

Received: 06.11.2019

Accepted: 15.01 .2020

Available Online Date: 27.11.2020

(C) Copyright 2020 by Pediatric Infectious Diseases and Immunization Society Available online at www.cocukenfeksiyon.org 


\section{Introduction}

Children with fever, malaise and arthralgia are often pre-diagnosed with several conditions including infectious, rheumatological and hematological diseases. Screening tests include mostly complete blood count, blood differential to exclude hematological diseases, inflamatory markers like C-reactive protein and spesific tests according to the pre-diagnosis like arthritis, osteomyelitis and many other conditions. However, if a disease is frequently seen or endemic in an area, it is possible to request some tests in first line. Serum agglutination tests for human brucellosis and salmonellosis have such an importance if the patient is living in an area, where animal disease is endemic and raw milk products are consumed. Both diseases are systemic and can lead to different clinical pictures. Brucellosis caused by bacteria Brucella spp. is a small, non-motile, non-spore-forming gram-negative coccobacilli (1). People in our country are still at high risk to acquire the disease via contact with sick animals or consumption of their milk and dairy products despite efforts to eradicate the disease (2). Moreover, salmonellosis is caused by an important human pathogen which is named Salmonella spp. and can lead to considerable morbidity and mortality due to intestinal and extraintestinal manifestations in the human body worldwide. People are infected mostly by eating foods like raw meat, poultry, eggs, and vegetables which are washed with contaminated water (3). Since both clinical entities can represent with similar manifestations, diagnostic tests are usually added in first line request for examination. This study was conducted with the purpose of showing ongoing importance, similarities and high frequency of both diseases in childhood.

\section{Materials and Methods}

The study was conducted in an endemic area in Turkey between November 2017 and November 2019. Thirty-six children admitted to the hospital with fever, fatigue and arthralgia and examined for endemic diseases especially if they had animal contact and found to be positive for brucellosis or salmonellosis were included to the study. Hospital records were screened for gender, age, consumption of row milk products, laboratory results, organ involvement, treatment choices and course of the disease. The study was approved by the local Ethics Committee.

\section{Microbiological Methods}

The diagnosis of acute brucellosis was based on positive culture or a single standard tube agglutination test (STA) against Brucella spp. of $\geq 1 / 160$.

For invasive salmonellosis, there are no reliable and rapid diagnostic tests available. Blood culture remains the gold standard but is insensitive, slow, and resource-intensive. In this study, basically STA tests were used for the diagnosis of both diseases. Titers higher than 1/100 in STA for salmonellosis were reported as positive. Blood cultures were drawn from patients with high fever.

\section{Results}

A total of 36 children who were admitted to the hospital between November 2017 and November 2019 with fever, malaise and arthralgia and suspected with brucellosis or salmonellosis and diagnosed with one of these diseases via standard agglutination tests were included into the study. Their clinical and laboratory findings, treatment modalities, prognosis and complications were evaluated. Out of these 36 children, 30 were diagnosed with brucellosis and 6 with salmonellosis. Sixteen were females (44\%) and 20 were males (56\%) with an age range 3-17 and a median age of 8.6. A total of 20 patients of the 30 cases $(66 \%)$ diagnosed with brucellosis notified exposure to animals as a possible infection source. Only two of these patients denied consumption of raw milk and dairy products. The rest confirmed usually that they had consumed cheese made with unpasteurized milk. Only 2 cases of the residual 6 cases diagnosed with salmonellosis had contact with animals and consumed raw milk or meat products. Their sources of infections remain unclear.

Fever (21/30 cases of brucellosis, $6 / 6$ of cases diagnosed with salmonellosis), malaise and arthralgia were most frequent symptoms and the reason for examinations. Hepatosplenomegaly was the most common extraarticular manifestation in both conditions. Physical signs and symptoms, laboratory findings of both disease groups are listed in Table 1. Standard tube agglutination tests and blood cultures were used for diagnosis, and patients were found positive either for brucellosis or salmonellosis. Only in one patient, who had liver involvement and a high titer as 1/5120 at the time of diagnosis, Brucella spp. was grown in the fifth day of incubation with BACTEC. Serological tests in brucellosis cases were repeated at the two weeks, one month and 3 months and if necessary, in follow up in case of relapse. The tests were repeated at the end of the treatment course and also if necessary, in patients with salmonellosis.

Children with brucellosis under the age of 8 years were treated with an aminoglycoside antibiotic for 5 to 7 days with combination of rifampicin and sulphamethoxazole/trimethoprim for 6 weeks. Older children were treated also with an aminoglycoside with combination of doxycycline and rifampicin also for 6 weeks. Disease relapse was seen in four of the total of 30 brucellosis cases. Patients with salmonellosis were treated with cephalosporins firstly with a parenteral ceftriaxone followed by a third-generation oral cephalosporin until their symptoms resolved.

All patients are in remission except two cases of brucellosis who had disease relapse in follow up, and one case who had 
Table 1. Physical signs, symptoms and laboratory findings of cases

\begin{tabular}{|c|c|c|c|c|}
\hline & \multicolumn{2}{|c|}{$\begin{array}{l}\text { Brucellosis } \\
(n=30)(\%)\end{array}$} & \multicolumn{2}{|c|}{$\begin{array}{l}\text { Salmonellosis } \\
(n=6)(\%)\end{array}$} \\
\hline Fever & \multicolumn{2}{|c|}{$21(70)$} & \multicolumn{2}{|c|}{$6(100)$} \\
\hline Malaise & \multicolumn{2}{|c|}{$26(86)$} & \multicolumn{2}{|c|}{$6(100)$} \\
\hline Arthralgia & \multicolumn{2}{|c|}{$20(66)$} & \multicolumn{2}{|c|}{$4(66)$} \\
\hline Hepatomegaly & \multicolumn{2}{|c|}{$5(16)$} & \multicolumn{2}{|c|}{$2(33)$} \\
\hline Splenomegaly & \multicolumn{2}{|c|}{$7(23)$} & \multicolumn{2}{|c|}{$3(50)$} \\
\hline $\begin{array}{l}\text { Hematological abnormalities (neutropenia, pancytopenia, } \\
\text { leukocytosis) }\end{array}$ & \multicolumn{2}{|c|}{$4(13)$} & \multicolumn{2}{|c|}{$1(16)$} \\
\hline Elevated transaminases & \multicolumn{2}{|c|}{$6(20)$} & \multicolumn{2}{|c|}{$1(16)$} \\
\hline STA titer at the time of diagnosis & $\begin{array}{c}>1 / 5120 \\
1 / 2560 \\
1 / 1280 \\
1 / 640 \\
<1 / 320\end{array}$ & $\begin{array}{c}7(24) \\
5(16) \\
10(34) \\
3(10) \\
5(16)\end{array}$ & $\begin{array}{c}1 / 6400 \\
1 / 800 \\
1 / 400 \\
1 / 200\end{array}$ & $\begin{array}{l}2(33) \\
1(17) \\
2(33) \\
1(17)\end{array}$ \\
\hline
\end{tabular}

hemophagocytosis, prolonged disease and needed additional chemotherapy.

Otherwise, patients were responded to the standard therapy with a mean of $7.6 \pm 5.9$ days and their symptoms resolved.

\section{Discussion}

Brucellosis is still an important public health problem, especially in the rural areas of Turkey (2). Data on the seroprevalence of brucellosis in children are very limited. They may constitute 20 to $30 \%$ of all cases in the world (1). Gul et al. reported in 2014 the seroprevalence of brucellosis cases among children in the Central Anatolia Region of Turkey as 64, 26, 10, 1, 4, and 2 in 2007, 2008, 2009, 2010, 2011, and 2012 respectively with ages younger than 18 years (4). They explain the sharp decrease in cases since 2009 as the result of new eradication programme. Celebi et al. have reported 62 pediatric cases diagnosed with brucellosis during an 8-year period in an endemic area in the same region where this study was conducted (5). In our study, we found the number of new cases in children as 30 in a two-year period. Despite effective precautions and eradication program, the number of new cases still remains to be high, which can be explained with high rate of husbandry practices and animal contact in the region. Other than direct contact with infected animals, the disease is also foodborne.

On the other hand, salmonellosis is highly seen worldwide and also endemic in our region. The European Centre for Disease Prevention and Control (ECDC) has reported that Salmonella is the second most common cause of foodborne outbreaks in the European Union (6). Most human salmonellosis cases are associated with consumption of contaminated eggs, milk and dairy products. Diagnosis is made usually via stool cultures if diarrhea is present. In our study, we examined only cases with symptoms of systemic infection like fever, malaise and arthralgia.

These symptoms are usually the rationale behind the examination of both diseases. Tuon et al. have reported fever, arthralgia and malaise as the most common symptoms in children with brucellosis in their large study group with percentages of $82 \%, 65 \%, 24 \%$ respectively (7). In our study $70 \%$ of the children had fever, $86 \%$ had malaise and $66 \%$ had arthralgia. In the salmonellosis group, children had similar symptoms but the number of cases were low to make a conclusion. The study would be more powerful if it was designed prospectively to show both the seropositivity and negativity of these diseases in children admitted to the hospital with fever, malaise and arthralgia.

Standard tube agglutination tests are indirect methods for diagnosis. However, they have an accuracy of $95 \%$ in brucellosis (7). In spite of that, there is no rapid and reliable test available for the diagnosis of invasive salmonellosis and related enteric fever. Commercially available serologic tests for typhoidal Salmonella have limited sensitivity and specificity. In high burden, resource-limited settings, reliance on clinical diagnosis or inaccurate tests often result in frequent, unnecessary treatment, which contributes selective pressure for the emergence of antimicrobial resistance. Most common diagnostic procedures are blood cultures and Gruber widal tests (8).

A single agglutination test has limited sensitivity and specificity, especially in endemic settings $(9,10)$. Monitoring 
of acute and convalescent titers improves test accuracy but has limited utility in guiding clinical practice $(11,12)$. In this study, patients had decreasing values of titers concordant with their clinical course. A definite diagnosis for brucellosis requires the isolation of the microorganism from blood, bone marrow or other tissues. However, cultural examinations are time-consuming and not sensitive (13). Similarly, the sensitivity of blood culture in salmonellosis has been variably reported at $40-80 \%$, with higher sensitivity in the first week of illness $(14,15)$. In our case series, we had both seropositivity and a positive culture result only in one patient. Other patients were diagnosed and monitored with serological titers. The study would be more powerful if the diagnosis was to be based on blood cultures which would be more reliable.

Since Brucella spp. are facultative intracellular microorganisms, treatment modalities include drugs like tetracyclines, aminoglycosides (amikacin, gentamycin, and streptomycin), quinolones (ciprofloxacin), rifampin, ceftriaxone, and sulphamethoxazole/trimethoprim $(16,17)$. Combined therapy is superior to monotherapy. At least two drugs should be used for treatment (A1). In children younger than 8 years of age, sulphamethoxazole/trimethoprim ( $10 \mathrm{mg} / \mathrm{kg} /$ day), plus rifampin ( $20 \mathrm{mg} / \mathrm{kg} /$ day) combined with an aminoglycoside for 5 to 7 days is usually treatment of choice in endemic areas where relapses are common. Children older than 8 years of age are treated mostly with an combination of doxycycline rather than sulphamethoxazole/trimethoprim. Total duration of the treatment is 6 weeks (18). In our study group, patients usually had good compliance to the treatment.

The other clinical entity caused by Salmonella spp. is usually treated with a third-generation cephalosporin for 10 to 14 days (19). Our patients were treated mostly for 10 days, but only one patient needed a prolonged course of treatment since her arthralgia persisted.

Another patient with prolonged course of disease was presented with high grade fever, malaise, jaundice, hepatosplenomegaly, pleural effusion and ascites in physical examination, pancytopenia, elevated transaminases, hyperbilirubinemia in laboratory examinations and diagnosed with hemophagocytosis lymphohistiocytosis (HLH) via bone marrow biopsy. He needed intensive care support and additional corticosteroid and IV immunoglobulin treatment to defeat the complications of the disease. HLH has been rarely reported in children with brucellosis but is actually not an unexpected clinical syndrome, and there are cases reported especially in regions were the disease is endemic $(20,21)$. Demir et al. have reported in a case series that hemophagocytosis was observed in 15 of 48 patients (31\%) in the $15-70$ age range (22).
Our patients treated with an appropriate regimen are in total remission, except the two cases of brucellosis. The rationale behind the relapses seems to be either incompliance or continuing exposure from different sources. Because in all cases, diagnostic procedures for suspected brucellosis infection in animals with direct contact with the patients are implemented.

In conclusion, despite effective eradication programs for both diseases, they still remain important health problems and cause disease burden. More effort should be made to eradicate brucellosis and to reduce the frequency of new cases of salmonellosis.

Ethics Committe Approval: The ethical approval for this study was obtained from Balikesir University Ethical Committee (Decision number: 198, Date: 05.10.2018)

Informed Consent: Patient consent was obtained.

Peer-review: Externally peer-reviewed.

Author Contributions: Concept - BYA, GA; Design - BYA; Supervision - BYA; Resource - BYA; Data Collection and/or Processing - BYA; Analysis and/or Interpretation - BYA; Literature Search - BYA; Writing - BYA; Critical Review - GA.

Conflict of Interest: No conflict of interest was declared by the authors.

Financial Disclosure: The authors declared that this study has received no financial support.

\section{References}

1. Uluğ M, Yaman Y, Yapici F, Can-Uluğ N. Clinical and laboratory features, complications and treatment outcome of brucellosis in childhood and review of the literature. Turk J Pediatr 2011;53:413-24. [CrossRef]

2. Yumuk Z, O'Collaghan D. Brucellosis in Turkey-an overview. Int J Infect Dis 2012;16:228-35. [CrossRef]

3. Sudharan S, Kanne P, Vemu L, Bhaskara A. Extraintestinal infections caused by nontyphoidal Salmonella from a tertiary care center in India. J Lab Physici 2018;10:401-5. [CrossRef]

4. Gül S, Satilmiş OK, Ozturk B, Gökçe MI, Kuscu F. Seroprevalence of brucellosis among children in the Middle Anatolia Region of Turkey. J Health Popul Nutr 2014;32:577-9. [CrossRef]

5. Celebi S, Hacımustafaoğlu M, Demirtaş F, Salı E, GülÜ, Özel M. Brucellosis in childhood. J Pediatr Inf 2011;5:59-62. [CrossRef]

6. Annual Epidemiological Report on Communicable Diseases in Europe. Available from: https://ecdc.europa.eu/en/publications-data/salmonellosis-annual-epidemiological-report-2015 Last accessed: 9 Ekim, 2018. [CrossRef]

7. Tuon FF, Cerchiari N, Cequinel JC, Droppa EEH, Moreira SDR, Costa TP, et al. Guidelines for the management of human brucellosis in the State of Paraná, Brazil. Rev Soc Bras Med Trop 2017;50:458-64. [CrossRef]

8. Andrews JR, Ryan ET. Diagnostics for invasive salmonella infections: current challenges and future directions. Vaccine 2015;33:C8-C15. [CrossRef] 
9. Parry CM, Hoa NT, Diep TS, Wain J, Chinh NT, Vinh H, et al. Value of a single-tube widal test in diagnosis of typhoid fever in Vietnam. J Clin Microbiol 1999;37:2882-6. [CrossRef]

10. Dutta S, Sur D, Manna B, Sen B, Deb AK, Deen JL, et al. Evaluation of new-generation serologic tests for the diagnosis of typhoid fever: data from a community-based surveillance in Calcutta, India. Diagn Microbiol Infect Dis 2006;56:359-65. [CrossRef]

11. House D, Chinh NT, Diep TS, Parry CM, Wain J, Dougan G, et al. Use of paired serum samples for serodiagnosis of typhoid fever. J Clin Microbiol 2005;43:4889-90. [CrossRef]

12. Willke A, Ergonul O, Bayar B. Widal test in diagnosis of typhoid fever in Turkey. Clin Diagn Lab Immunol 2002;9:938-41. [CrossRef]

13. Al Dahouk S, Tomaso H, Nöckler K, Neubauer H, Frangoulidis D. Laboratory-based diagnosis of brucellosis-a review of the literature. Part II: serological tests for brucellosis. Clin Lab 2003;49:577-89. [CrossRef]

14. Gilman RH, Terminel M, Levine MM, Hernandez-Mendoza P, Hornick RB. Relative efficacy of blood, urine, rectal swab, bone-marrow, and rosespot cultures for recovery of Salmonella typhi in typhoid fever. Lancet 1975;1:1211-3. [CrossRef]

15. Wain J, Diep TS, Bay PVB, Walsh AL, Vinh H, Duong NM, et al. Specimens and culture media for the laboratory diagnosis of typhoid fever. J Infect Dev Ctries 2008;2:469-74. [CrossRef]
16. Bayram Y, Korkoca H, Aypak C, Parlak M, Cikman A, Kilic S, et al. Antimicrobial susceptibilities of Brucella isolates from various clinical specimens. Int J Med Sci 2011;8(3):198-202. [CrossRef]

17. Bodur H, Balaban N, Aksaray S, Yetener V, Akinci E, Colpan A, et al. Biotypes and antimicrobial susceptibilities of Brucella isolates. Scand J Infect Dis 2003;35:337-8. [CrossRef]

18. Christenson JC. Brucellosis. In: Jenson HB, Baltimore RS (eds). Pediatric Infectious Diseases. $2^{\text {nd }}$ ed. Philadelphia: WB Saunders Company, 2002:379-82. [CrossRef]

19. Feigin RD. Salmonella. Feigin and Cherry's Textbook of Pediatric Infectious Diseases. $7^{\text {th }}$ ed. Philadelphia, Chapter 111. [CrossRef]

20. Pekpak E, Sirvan Cetin B. Secondary hemophagocytic lymphohistocytosis in a child with brucellosis. J Pediatr Hematol Oncol 2017;39:501-3. [CrossRef]

21. Mondal N, Suresh R, Acharya NS, Praharaj I, Harish BN, Mahadevan S. Hemophagocytic syndrome in a child with brucellosis. Indian J Pediatr 2010;77:1434-6. [CrossRef]

22. Demir C, Karahocagil MK, Esen R, Atmaca M, Gönüllü H, Akdeniz H. Bone marrow biopsy findings in brucellosis patients with hematologic abnormalities. Chin Med J (Engl) 2012;125:1871-6.[CrossRef] 